\title{
Aspects of Temporality in Greek Magical Papyri
}

\author{
Andrea Salayová \\ (Masaryk University, Brno)
}

\begin{abstract}
The aim of this study is to analyse the aspects of temporality in Greek magical papyri. The research presented in this paper is divided into two conceptual parts. In the first part, the paper focuses on the question, which time (i.e. of the day/month/year) is the most suitable to perform the spell-ritual according to papyri-texts. In the second part, the paper deals with the question of duration with regard to the performance of spell-rituals. These questions are evaluated quantitatively by the means of the statistical analysis, which offers a more systematic and detailed understanding of the temporal dynamics in practice of magic in antiquity. A key source for this study was the Betz's edition of the Greek magical papyri (1986), compared to the Preisendanz's Papyri Graecae magicae: die griechischen Zauberpapyri (2001).
\end{abstract}

\section{Keywords}

ancient magic; Greek magical papyri; ritual time; temporality 


\section{Introduction}

Various aspects of temporality have always been deeply connected to human ritualistic behaviour. The solar and lunar cycles were basis for the large number of religious practices and magical rituals. ${ }^{1}$ This paper is trying to observe and evaluate the various aspects of temporality in the rituals described in the Greek magical papyri. ${ }^{2}$

The analysis of the text within the Greek magical papyri offers the following research questions with respect to time: How much time did it take to perform these rituals? Does the amount of time needed to perform the ritual say something about its significance? It will also research other aspects of time in connection to the rituals - which time of the day was the most suitable for performing the spell-ritual? Do certain kinds of spells require certain times of the day, or is it the darkness of the night that is generally needed, as was indicated by Apuleius in Metamorphoses? ${ }^{3}$

The research questions mentioned above will be approached by the quantitative analysis of the Greek magical papyri and comparison to the accounts of the classical authors.

\section{Astronomical time}

Since the Greek magical papyri are very detailed in nature, they contain the description of the spells, ingredients needed for them, prayers and invocations to be said. They also often specify the time when the spell is supposed to be performed to obtain the best results. Out of the 532 papyri-texts ${ }^{4}$ in the collection by Betz from 1986, 87 contain some indication on suitable time of the spell performance. ${ }^{5} 54$ papyri-texts indicate the time of the day, 42 time of the month, and 3 time of the year.

\section{Time of the day}

According to modern folklore and ancient sources (as listed below), we would expect the most suitable time to perform magic to be the night. From the ancient sources, we can find this opinion in Apuleius's Metamorphoses (Golden Ass), where the slave girl Photis explains to Lucius the magical powers of her mistress:

1 For more about the definition of magic and difference between the magic and religion see Mauss \& Hubert (2014: pp. 97-110); Malinowski (2014: pp. 156-171); Graf (2002: pp. 92-104); Johnston (2007: pp. 139-154). It is not a point of this paper to argue the definition of magic or its comparison to religion.

2 For more background on Greek magical papyri, see Betz (1986: pp. xli-lviii).

3 Apul. Met. 3,16.

4 Counting as divided by Betz in Table of spells (Betz 1986: pp. xi-xxii).

5 See Add.1. - List of all the papyri-texts in Betz' collection containing time reference. 
Audivi vesperi, meis his, inquam, auribus audivi, quod non celerius sol caelo ruisset noctique ad exercendas inlecebras magiae maturius cessiset, ipsi soli nubilam caliginem et perpetuas tenebras commitantem. ${ }^{6}$

"and I heard her threaten with mine own ears yesternight, that because the sun had not then presently gone down and the night come to minister convenient time to work her magical enticement, she would veil the same sun with a thick shadow of cloud and bring perpetual darkness over all the world."

Interesting about this account is that it shows solely the night as suitable to perform magic and suggests that during the day it would not be possible. Otherwise the witch would not have threatened the sun. This is not the only time when the author expresses this belief. Apuleius also mentions the night as the most suitable time to perform magic in Apologia:

Magia ista, quantum ego audio, res est legibus delegata, iam inde antiquitus XII tabulis propter incredundas frugum inlecebras interdicta, igitur et occulta non minus quam tetra et horribili, plerumque noctibus vigilata et tenebris abstrusa et arbitris solitaria et carminibus murmurata. ${ }^{8}$

"Now this magic of which you accuse me is, I am told, a crime in the eyes of the law, and was forbidden in remote antiquity by the Twelve Tables because in some incredible manner crops had been charmed away from one field to another. It is then as mysterious an art as it is loathly and horrible; it needs as a rule night-watches and concealing darkness, solitude absolute and murmured incantations, to hear which few free men are admitted, not to speak of slaves."

Here he states that magic needs night-watches and darkness as a rule, and the way this fact is plainly stated might suggest that this was somehow common public knowledge or part of the folklore during that time. We can find the similar opinions among the texts of other authors, as well. Among others in Ovid's Metamorphoses, in the part where Medea is talking about her own magical powers:

Nox, ait, arcanis fidissima, quaeque diurnis

aurea cum luna succeditis ignibus astra,

tuque, triceps Hecate, quae coeptis conscia nostris

adiutrixque venis cantusque artisque magorum, ${ }^{10}$

"Night, most faithful keeper of our secret rites;

Stars, that, with the golden moon, succeed the fires of light;

6 Apul. Met. 3,16.

7 Apuleius (1947: p. 125).

8 Apul. Apol. 47,1.

9 Transl. Butler (2008: p. 48).

10 Ov. Met. 7,192-209. 
Triple Hecate, you who know all our undertakings, and come, to aid the witches' art, and all our incantations"11

We can also find reference to the night in Ovid's Amores, which is very similar to the account of Apuleius and behaviour of his witch, who turned herself into a bird, and this change was described in detail, including the part where she grew the feathers, which is mentioned by Ovid:

\section{hanc ego nocturnas versam volitare per umbras \\ suspicor et pluma corpus anile tegi. ${ }^{12}$ \\ "I suspect she changes, at will, in the shadows of night and her old woman's body grow feathers." 13}

Another author, who connects the night to the magic is Tibullus, who hints at this in Elegies, where a man (poet himself) is making a ritualistic promise for the ill girl he loves (Delia) - in the middle of the night.

ipse ego velatus filo tunicisque solutis

vota novem Triviae ${ }^{14}$ nocte silente dedi. ${ }^{15}$

"I myself in woollen headband and loose tunic

offered nine vows to Trivia in the silent night." 16

Similarly, Tibullus mentions the night in 1.8.17-28, which is again described as silent:

Num te carminibus, num te pallentibus herbis

devovit tacito tempore noctis anus? ${ }^{17}$

"Has some old woman bewitched you with her chants, or pallid herbs, in the silent hours of night?" 18

11 Transl. Kline (2004: p. 331).

12 Ov. Am. 1,8,1-23.

13 Transl. Kline (2001: p. 26).

14 Trivia - "goddess who haunted crossroads, graveyards, and was the goddess of sorcery and witchcraft, she wandered about at night and was seen only by the barking of dogs who told of her approach" - Zimmerman (1964: p. 278).

15 Tib. 1,5,9-18.

16 Transl. Kline (2001a: p. 16).

17 Tib. 1,8,17-28.

18 Transl. Kline (2001a: p. 24). 
The mentions of the night in connection to magic are not surprising, since the darkness of the night can not only cover the often forbidden magical deeds, but also give the ritual more magical atmosphere. It seems that these opinions were present in the folklore of the time and they are reflected in the literature as well. However, in the Greek magical papyri we can find all times of the day prescribed as the time suitable to perform certain spells. Very often, the most suitable time is the sunrise, sometimes attested with the exact hour needed for the best results.

Sunrise is indicated as the suitable time for the performing of the spell most often, present in 29 papyri-spells. Night is mentioned in 16 of them. Only other mentioned times of the day are evening ( 7 times) and midday, which is only mentioned in combination with other times of the day, never on its own.

The question, why the sunrise is indicated in the most papyri spells as a suitable time to perform a spell can be possibly answered by its significance. The start of the new day, the "birth" of the sun was believed to have magical powers, which could help in creating the spell power. This belief is reflected in many religions and cults worshipping the sun as a personification of a god..$^{19}$ Among the Romans, the cult of Sol Invictus ("Unconquered Sun") was favoured among the emperors ${ }^{20}$ and gained much popularity, especially among the soldiers. ${ }^{21}$

\section{Time of the week}

Time of the week is not indicated often in the papyri spells; the only example is the one given below. This could be explained by the higher importance of the lunar calendar, ${ }^{22}$ since the weekly cycle is "entirely dissociated from the lunar cycle". ${ }^{23}$

Time of the week is listed in PGM IV. 1-25, which is titled "The spell for revelation". The spell begins with the calling for "the great daimon" and the sequence of the voces magicae. ${ }^{24}$ After that the text mentions the day of the week:

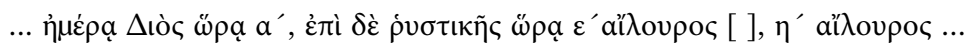

“... on the day of Zeus (Thursday) in the first hour, but on the day of deliverance (Sunday) in the fifth hour...”

19 For more on solar deities see Kraus (2016: pp.137-141); Gralha (2008: pp. 167-174); Dexter (1984: pp. 137-144); Halsberghe (2015: pp. 38-44).

20 Especially Aurelian (214/215-275 CE) see Halsberghe (2015: pp.131-171); and Constantin (272-337 CE), but it was also connected to other emperors, like Septimius Severus (145-211 CE) or Probus (232-282 $\mathrm{CE})$, who both portrayed this god on the coins.

21 Halsberghe (2015: pp. 26-37).

22 For more on Roman calendar, see Laurence \& Smith (1996: pp. 133-151).

23 Zerubavel (1985: p. 9).

24 Magical words seemingly without meaning, used to strenghten the atmosphere of the spell and help with the invocation of magical powers. Some of them could allude to the names of obscure gods or daimons. 
The text then ends with the part meant to be spoken - the invocation of various gods.

\section{Time of the month}

The time of the month suitable for performance of a spell is indicated in 42 papyri spells. This time is based on lunar calendar, counting usually from the new moon. ${ }^{25}$ New moon and full moon are present as the important days for magic, but not as important as we would have expected. They are only mentioned two times. More often the spell calls for a certain day number (3rd day, 14th day etc.) or the phase of the moon (waning moon most often) or the moon being in certain zodiac sign.

A very interesting take on temporality can be seen in this papyri spell, titled "the Lunar horoscope" - PGM III. 275-281, which explains which lunar zodiac signs are the most suitable to perform certain types of magical spells:

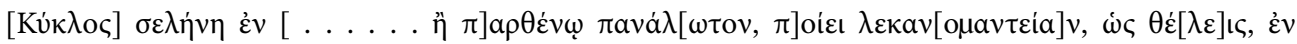

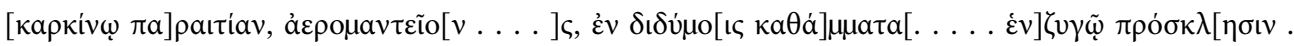

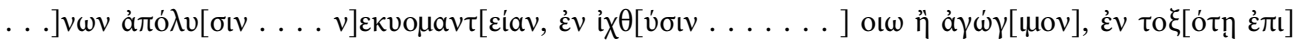

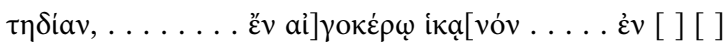

"(Zodiac)Moon in Virgo: anything is obtainable, perform bowl divination, as you wish, in Cancer: perform the spell of reconciliation, air divination ... in Gemini: perform spells of binding, ... in Libra: perform invocation ... spell of release ... necromancy, in Pisces ... OIO or love charm, in Sagittarius: conduct business, in Capricorn: do what is appropriate, in...”

These observations of the planets and their influence on everyday life (including magic) are not uncommon for people in antiquity, especially Egyptians during the time the Greek magical papyri originated. ${ }^{26}$ This is also attested in the literature in the account of the Diodorus of Sicily, which he wrote between the year 60 and 30 BCE: „The positions and the arrangements of stars, as well as their motion, have always been the subject of careful observation among the Egyptians, if anywhere in the world..." 27 That might also be a reason why there are these instructional papyri-texts, mentioning the best time to perform certain kinds of spells based on astrology.

In other instances, the papyri texts mention the time of the month not based on zodiac signs and simply working with the days of the calendar month as in PGM IV. 26-51, titled "the Initiation" and PGM V. 213-303, titled "the Hermes' ring", where the exact days of the month are indicated:

25 For more on ancient egyptian astrology see Barton (2016: pp. 19-29).

26 2nd century BCE-5th century CE (Betz 1986: p. 41).

27 Barton (2016: p. 24). 
PGM IV. 26-51:

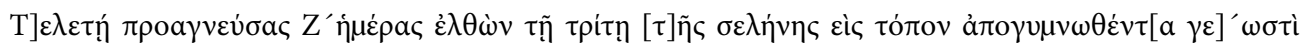

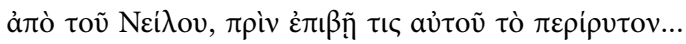

“*Initiation: Keep yourself pure for 7 days beforehand. On the third of the month, go to a place from which the Nile has recently receded, before anyone walks on the area that was flooded."

PGM V. 213-303:

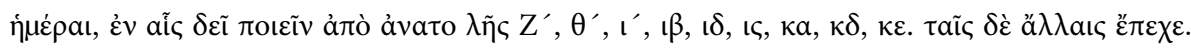

"The days in which it is proper to perform this rite are, counting from the rise of the new moon the 7 th, 9 th, 10th, 12th, 14th, 16th, 21st, 24th, 25th. On the others, restrain yourself."

\section{Time of the year}

Not many papyri spells refer to specific time of the year, but when they do, they indicate the specific date, rather than longer period of time. The only three "special" days mentioned in connection to year are in these three papyri spells: PDM XIV. 875-885 ("when the sun fills the sound eye"), ${ }^{28}$ PGM XXVIIIa. 1-7 (" $15^{\text {th }}$ day of Pachon" $)^{29}$ and PGM XXVIIIc. 1-1 ("4th day of Phamenoth"). ${ }^{30}$

\section{Time needed to perform the spell}

Other interesting aspect of temporality in the Greek magical papyri is the duration of the spell ritual, in other words - how long did it take to complete the ritual. To be able to research this question in detail, it was necessary to divide the spell into three parts: preparation, performance and effect of the spell.

\section{Preparation}

Preparation for the spell consists of the tasks that need to be done before the actual ritual could take place, usually the purification period and the gathering of the ingredients. The purification is the time needed for the performer to cleanse themselves, both

28 Meaning summer solstice (Betz 1986: p. 240).

29 The ninth month of the later ancient Egyptian civil calendar and Coptic calendar. For more on Egyptian calendars and dating systems see Hornung \& Krauss \& Warburton (2006: pp. 45-54).

30 The seventh month of the later ancient Egyptian civil calendar and Coptic calendar. 
literally and figuratively. This purification period could consist of not eating certain foods or abstaining from various kinds of activities. Usually the spell specifies the amount of time needed to be spent in the purification phase. As an example, see PGM IV. 26-51 above, where the purification period consists of seven days. The number of days in other papyri-spells varies and highly contributes to the overall time needed to perform the spell. However, the purification is not the only action to be taken in the preparation phase of the spell-ritual. The time needed for other actions to be done can vary from several minutes, as in for example PGM III. 263-275, titled "Foreknowledge charm":

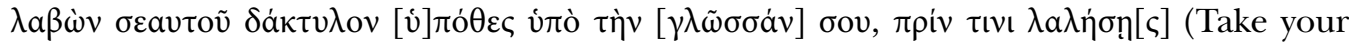
finger and place it under your tongue before you speak to anyone) to several days, as in PGM II. 64-183, titled "Alternative spell for revelation", where the preparation for the spell takes 7 days:

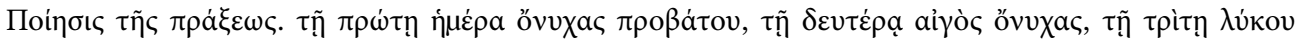

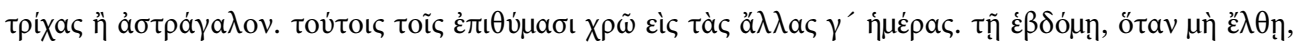

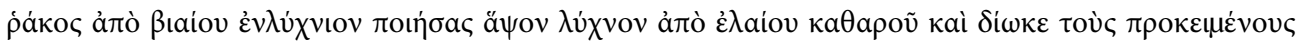
$\lambda$ ójous...

"On the first day, collect nails of sheep, on the second, the nails of goat, on the third, the hair or knucklebone of a wolf. Use these as burnt offering for the next three days. On the seventh day, in case he does not yet come ... recite the prescribed formulas...”

Sometimes the preparation can take even longer because of the very long purification period, as in PGM XIII. 1-343, titled "A sacred book called 'Unique' or Eight book of Moses":

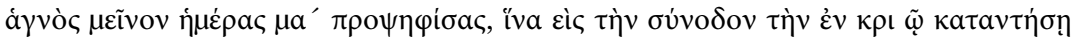

"Remain pure 41 days, having calculated in advance so that your completion of them will coincide with the dark of the moon which occurs in Aries." ${ }^{31}$

And sometimes the preparation does not take that many days, but it seems tedious all the same, as in PGM XIII. 646-734, which is titled "a different version of the incantation ritual":

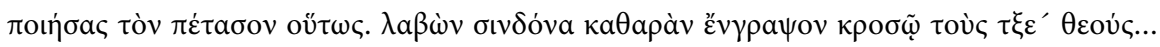

„Prepare the canopy thus: taking a clean sheet, write on the border the names of 365 gods...”

\section{Performance}

Performance is the part of the spell which requires action, as listed in the recipe - using the ingredients, doing sacrifice, saying invocations. It usually does not take as much time

31 Similarly also PGM XIII. 343-646. 
as the preparation, since this part is the most straightforward and clearly stated.

\section{Effect}

Two types of the spell-effects can be observed within the rituals of the Greek magical papyri. Effect of the spell can be either limited or unlimited and both can be often seen within the same spell. Limited effect, i.e. lasting only until the desired effect is achieved, can often be seen in love spells, as in PGM IV. 296-466, which is titled "A wondrous spell for binding a lover":

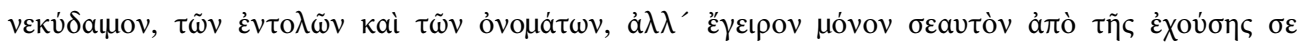

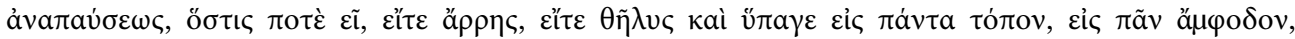

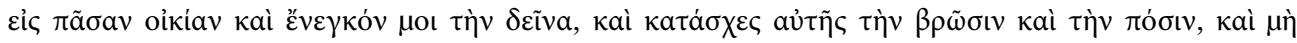

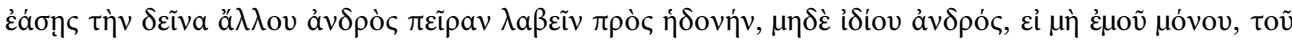

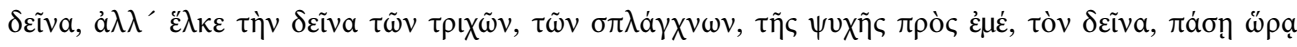

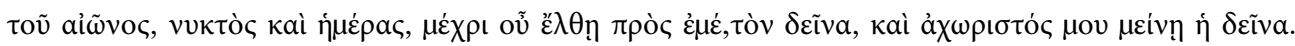

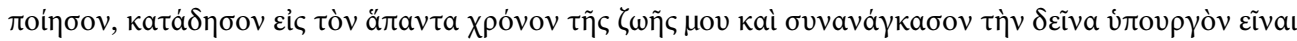

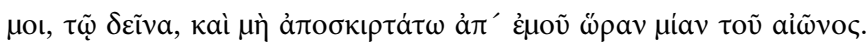

"Do not fail, god of the dead, to heed my commands and names, but just arouse yourself from the repose which holds you, whoever you are, whether male or female, and go to every place, into every quarter, into every house, and attract her, $\mathrm{NN}$, to me and with a spell keep her from eating and drinking, and do not allow her, $\mathrm{NN}$, to accept for pleasure the attempt of another man, not even that of her own husband, just that of mine, NN. Instead, drag her, NN, by the hair, by her heart, by her soul, to me, NN, at every hour of life, day and night, until she comes to me, NN, and may she remain inseparable from me. Do this, bind her for all the time of my life and help force her, $\mathrm{NN}$, to be serviceable to me, $\mathrm{NN}$, and let her not frolic away from me for even one hour of life."

The limited effect of the spell can be seen in the first part of the text ("drag her, NN, by the hair, by her heart, by her soul, to me, NN, at every hour of life, day and night, until she comes to me"). Towards the end, the unlimited effects of the spell are listed ("bind her for all the time of my life and help force her, NN, to be serviceable to me, NN, and let her not frolic away from me for even one hour of life"). This combination of limited and unlimited effects of the spell is very typical for love-spells.

Limited effect of the spell can also be often found in invisibility spells, which are supposed to work until the spell is revoked by performing a special task or waiting until a certain time has passed. This can be seen in PGM I. 222-231, which is titled "Invisibility spell":

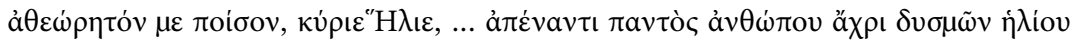


"Make me invisible, lord Helios, ... in the presence of any man until sunset."

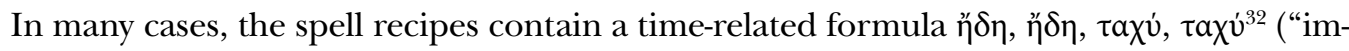
mediately, immediately, quickly, quickly"), which is supposed to help the spell take the desired effect quicker. This can be seen in PGM I. 247-262, which is titled "Tested spell for invisibility":

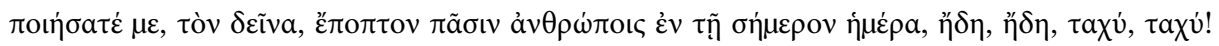

„Make me, NN, visible to all men on this day, immediately, immediately, quickly, quickly!”

\section{Possible explanations}

The question then arises, why would people perform these complicated and often timeconsuming rituals? ${ }^{33}$ Unlike the official state religions and organized cults, performing magic was not a society binding tool. Fritz Graf argues,${ }^{34}$ that in the perfect society, magic would cease to exist, since it is based on human distrust and fear. It was often performed in secrecy and forbidden by law, ${ }^{35}$ so its performers risked negative consequences. Was the outcome of the spell-ritual something so desired that it was the only reason why people turned to magic? Or was there something in the process itself, that made magic desirable? One of the possible explanations could be found in the effects of the spells. When in a dire situation, with no other viable way to influence its outcome, people turned to magic as a form of having control over the situation, that was otherwise outside of their reach. Spells for finding thieves or even the love-spells are the perfect example. But that still doesn't explain why many of the ritual-spells were so complicated and demanded considerable amounts of time to perform. If the effect was the only reason for performing magic, would it matter if the ritual was more complicated? And this also brings the question: Does the complexity and length of the spell increase the chance of better outcome in the eyes of the performers of magic? Especially considering the belief that every step of the ritual needed to be performed perfectly for the desired outcome, wouldn't the higher complexity of the spell mean much more space for mistakes? Maybe answers to these questions can provide the research into ritual itself and ritualistic behaviour provided by the cognitive science of religion. One of the recent theories of cognitive behavioural studies by Liénard and Boyer ${ }^{36}$ suggests, that the length and the complexity of the ritual could be directly connected to the feelings of satisfaction in the human brain. Responsible for this is the so called "Hazard precaution

32 These time formulae can be also found on numerous places in curse tablets, for more see Urbanová (2018: $\S 3.3 .1,3.3 .1 .1)$.

33 For more on rituals in general see Bremmer (2007: pp. 32-44).

34 Graf (2002: p. 98).

35 For more on sancions on magic in antiquity, see Phillips (1997: pp. 260-276).

36 Liénard \& Boyer (2006: pp. 1-59). 
system", a mechanism in the brain, according to which the brain is highly susceptible to any signs of possible danger and it tries to avoid it by performing any kind of ritual, even if it seems unrelated to any kind of danger. Simple prescribed steps of the ritual can help to placate the brain's Hazard precaution system and the more complicated and longer these steps are, the higher the feeling of satisfaction is. This might be also an explanation why people didn't question these time-consuming rituals - it provided them with pleasant feelings of satisfaction. This of course applies to any kind of ritualistic behaviour, not only to the rituals in the Greek magical papyri, but it could be a part of the explanation for their complexity without the society-binding context. The need for more detailed research of the reasons behind the rituals was also expressed by Marshall: ${ }^{37}$ "Most thinking about rituals in recent years has focused on their symbolic content, maintaining that ritual is merely one more medium in which ideas are symbolically expressed, transmitted, and reinforced. But such an approach cannot explain why these particular messages are expressed in this particular way".

\section{Conclusion}

The time is an important factor in the spells of Greek Magical Papyri, no matter whether it is the time needed to perform the spell, or the time of day the most suitable for the task. It was found out that despite the popular opinions on the matter by the ancient authors and modern folklore together, night was not the most suitable time to perform magic - it was the sunrise, at least as far as the spells in Greek Magical Papyri mention.

As to why people perform these complicated and time-consuming spells at all, if we use the cognitive science of religion theory, it could be because they just want to feel like they are doing something to achieve the result, which is otherwise outside of their powers. And the more complicated the task, the bigger the feeling of the satisfaction is. Of course, the survey of the reasons to perform these complicated rituals is preliminary. It should raise questions and prompt the further interdisciplinary research into the topic of magical rituals in antiquity.

Add.1: List of Betz' papyri-texts containing time reference (duration of the spell or suitable time for its performance):

PGM I. 1-42, PGM I. 42-195, PGM II. 1-64, PGM II. 64-183, PGM III. 1-164, PGM III. 275-81, PGM III. 282-409, PGM III. 424-466, PGM III. 612-632, PGM IV. 1-25, PGM IV. 26-51, PGM IV. 52-85, PGM IV. 154-285, PGM IV. 286-295, PGM IV. 296466, PGM IV. 475-829, PGM IV. 835-849, PGM IV. 850-929, PGM IV. 930-1114, PGM. IV. 1265-1274, PGM IV. 1872-1927, PGM IV. 2145-2240, PGM IV. 2373-2440, PGM IV. 2441-2621, PGM. IV. 2622-2707, PGM IV. 2708-2784, PGM IV. 3086-3124,

37 Marshall (2002: p. 361). 
PGM IV. 3125-3171, PGM IV. 3172-3208, PGM IV. 3209-3245, PGM V. 213-303, PGM V. 304-369, PGM V. 370-446, PGM VI. 1-47, PGM VII. 155-167, PGM VII. 222-249, PGM VII. 272-283, PGM VII. 284-299, PGM VII. 300a-310, PGM VII. 319-334, PGM VII. 319-334, PGM VII. 359-369, PGM VII. 417-22, PGM VII. 429-458, PGM VII. 505-525, PGM VII. 740-755, PGM VII. 846-861, PGM VII. 862-918, PGM VII. 981-993, PGM XII. 1-13, PGM XII. 14-95, PGM XII. 270-350, PGM XII. 351-364, PGM XII. 376-396, PGM XIII. 1-343, PGM XIII. 343-646, PGM XIII. 646-734, PGM XIII. 734-1077, PDM XIV. 232-239, PDM XIV. 239-295, PDM XIV. 309-334, PDM XIV. 335-355, PDM XIV. 355-365, PDM XIV. 475-488, PDM XIV. 636-669, PDM XIV. 675-694, PDM XIV. 695700, PDM XIV. 701-705, PDM XIV. 772-804, PDM XIV. 856-875, PDM XIV. 875-885, PDM XIV. 1003-1014, PDM XIV. 1078-1089, PDM XIV. 1141-1154, PDM XIV. 11801181, PGM XXVIIIa. 1-7, PGM XXVIIIb. 1-9, PGM XXVIIIc. 1-1, PGM XXXVI. 320332, PGM LXXII. 1-36, PGM LXXXVI. 3-7, PGM XCV. 7-13, PDM Suppl. 19-27, PDM Suppl. 60-101, PDM Suppl. 117-130, PDM Suppl. 130-138, PDM Suppl. 168-184.

\section{Bibliography}

\section{Primary sources}

Adlington, W. (Transl.). (1947). The Golden Ass. Being the Metamorphoses of Lucius Apuleius. London: Harvard University Press.

Betz, H. D. (1986). The Greek Magical Papyri. Chicago: Chicago Univ. Press.

Butler, H. E. (Transl.). (2008). Apuleius: The Defense (web edition). Adelaide: The University of Adelaide Library [retrieved 22.04.2018 from https://ebooks.adelaide.edu.au/a/apuleius/defense/complete.html].

Butler, H. E., \& Owen, A. S. (Eds.). (1914). Apuleii Apologia. With Introduction and Commentary. Oxford: Clarendon Press [rev. by S. Gaselee (1916), The Classical Review, 30(03), 93-94].

Helm, R. (Ed.). (1994). Apvlei Platonici Madavrensis Opera quae supersunt, Vol. 2, Fasc. 1: Pro se de magia liber. Stuttgardiae: Teubner.

Katz, V. (Ed.). (2004). The Complete Elegies of Sextus Propertius. Princeton, NJ: Princeton University Press.

Kline, A. S. (Transl.). (2001). Ovid: The Amores [retrieved 22.04.2018 from http://uploads.worldlibrary.net/uploads/pdf/20121106024016ovidamorespdf_pdf.pdf].

Kline, A. S. (Transl.). (2001a). Tibullus and Sulpicia: The Poems [retrieved 22.04.2018 from https:// www.poetryintranslation.com/klineastibullus.php].

Kline, A. S. (Transl.). (2004). Ovid: Metamorphoses. Ann Arbor: Borders Classics.

Lenz, F. W. (1967). Ovid's Metamorphoses. Prolegomena to a Revision of Hugo Magnus' Edition. Dublin: Weidmann.

Magnus, H. (Ed.). (1914). Ovidius: Metamorphoseon libri XV. Berolini: Weidmann.

Merkel, R., \& Ehwald, R. (Eds.). (1907). Amores. Epistulae. Medic. fac. fem. Ars amat. Remedia amoris. Lipsiae: In aedibus B. G. Teubneri.

More, B. (Transl.). (1953-1957). Ovid's Metamorphoses ... in English Blank Verse (3 vols.). Francestown, NH: Marshall Jones Co. 
Postgate, J. P. (Ed.). (1940). Selections from Tibullus and Others (2nd ed.). London: Macmillan.

Preisendanz, K., \& Henrichs, A. (Eds.). (2001). Papyri Graecae magicae. Die griechischen Zauberpapyri (2nd ed., repr.). München: K. G. Saur.

\section{Secondary sources}

Barton, T. (2016). Ancient astrology. New York: Routledge.

Betz, H. D. (1997). Magic and Mystery in the Greek Magical Papyri. In C. A. Faraone, \& D. Obbink (Eds.), Magika hiera: Ancient Greek Magic and Religion (pp. 244-259). New York: Oxford University Press.

Bremmer, J. (2007). Ritual. In S. I. Johnston (Ed.). Ancient Religions: Beliefs and Rituals across the Mediterranean World (pp. 32-44). Cambridge, MA: Harvard University Press.

Collins, B. J. (2015). Necromancy, Fertility and the Dark Earth: The Use of Ritual Pits in Hittite Cult. In P. A. Mirecki, \& M. W. Meyer (Eds.). Magic and Ritual in the Ancient World (pp. 224-241). Leiden: Brill.

Dexter, M. R. (1984). Proto-Indo-European Sun Maidens and Gods of the Moon. Mankind Quarterly, 25, 137-144.

Faraone, C. A., \& Obbink, D. (1997). Magika hiera: Ancient Greek Magic and Religion. New York: Oxford University Press.

Graf, F. (2015). Theories of Magic in Antiquity. In P. A. Mirecki, \& M. W. Meyer (Eds.), Magic and Ritual in the Ancient World (pp. 92-104). Leiden: Brill.

Gralha, J. (2008). Power and Solar Cult in Ancient Egypt. In P. P. Funari, R. S. Garraffoni, \& B. Letalien (Eds.), New Perspectives on the Ancient World: Modern Perceptions, Ancient Representations (pp. 167-174). Oxford: Archaeopress.

Halsberghe, G. (2015). Cult of Sol Invictus. Boston: Brill.

Hornung, E., Krauss, R., \& Warburton, D. (2006). Ancient Egyptian Chronology. Leiden: Brill.

Johnston, S. I. (2007). Ancient Religions: Beliefs and Rituals across the Mediterranean World. Cambridge, MA: Harvard University Press.

Krauss, R. (2016). Stellar and Solar Components in Ancient Egyptian Mythology and Royal Ideology. In M. A. Rappenglück, B. Rappenglück, N. Campion, \& F. Silva (Eds.), Astronomy and Power: How Worlds are Structured. Proceedings of the SEAC 2010 Conference (pp. 137-142). Oxford: British Archaeological Reports Ltd.

Laurence, J., \& Smith, C. (1996). Ritual, Time and Power in Ancient Rome. The Journal of the Accordia Research Institute, 6, 133-151.

Liénard, P., \& Boyer, P. (2006). Why Ritualized Behaviour? Precaution Systems and Action Parsing in Developmental, Pathological and Cultural Rituals. Behavioural and Brain Sciences, 29, 1-59.

Malinowski, B. (2014). Magic, Science and Religion. In B. Otto, \& M. Stausberg (Eds.), Defining Magic (pp. 156-171). Hoboken: Taylor and Francis.

Marshall, D. A. (2002). Behavior, Belonging, and Belief: A Theory of Ritual Practice. Sociological Theory, 20(3), 360-380.

Mauss, M., \& Hubert, H. (2014). A General Theory of Magic. In B. Otto, \& M. Stausberg (Eds.), Defining Magic (pp. 97-110). Hoboken: Taylor and Francis.

Mirecki, P. A., \& Meyer, M. W. (Eds.). (2015). Magic and Ritual in the Ancient World. Leiden: Brill. 
Otto, B., \& Stausberg, M. (2014). Defining Magic. Hoboken: Taylor and Francis.

Phillips, C. R. (1997). Nullum crimen sine lege: Socioreligious Sanctions on Magic. In C. A. Faraone, \& D. Obbink (Eds.), Magika hiera: Ancient Greek Magic and Religion (pp. 260-276). New York: Oxford University Press.

Urbanová, D. 2018. Latin Curse Tablets of the Roman Empire. Innsbruck: Innsbrucker Beiträge zur Kulturwissenschaft.

Zerubavel, E. (1985). The Seven Day Circle. The History and Meaning of the Week. Chicago: The University of Chicago Press.

Zimmerman, J. E. (1964). Dictionary of Classical Mythology. New York: Harper \& Row.

Mgr. Andrea Salayová / asalayova@gmail.com

Department of Classical Studies

Masaryk University, Faculty of Arts

Arna Nováka 1, 60200 Brno, Czech Republic 